\title{
A Review of Flavobacterium Psychrophilum Biology, Clinical Signs, and Bacterial Cold Water Disease Prevention and Treatment
}

\author{
Michael E. Barnes ${ }^{1, *}$ and Michael L. Brown ${ }^{2}$ \\ ${ }^{I}$ South Dakota Department of Game, Fish and Parks McNenny State Fish Hatchery 19619 Trout Loop Spearfish, South \\ Dakota USA 57783 \\ ${ }^{2}$ South Dakota State University Department of Wildlife and Fisheries Sciences Box 2140B, SNP 138 North Campus \\ Drive Brookings, South Dakota USA 57007
}

\begin{abstract}
Bacterial coldwater disease and other infections caused by Flavobacterium psychrophilum are a worldwide concern, particularly for freshwater salmonid hatcheries. F. psychrophilum infections can be difficult to control; antibiotic resistance is common and no effective vaccines are currently available. This review summarizes the biology and characteristics of this important pathogen, as well as the techniques required for isolation and identification. In addition, the epidemiology, clinical signs, treatment, and possible preventative measures of bacterial coldwater disease are discussed.
\end{abstract}

Keywords: Bacterial coldwater disease, Flavobacterium psychrophilum, salmonid, pathogenic bacteria.

\section{INTRODUCTION}

Flavobacterium psychrophilum is a ubiquitous bacterium in the aquatic environment, particularly in freshwater [1]. As the etiological agent of bacterial coldwater disease, it is a serious fish pathogen causing substantial economic losses and rearing difficulties to both commercial and conservation aquaculture [2]. This review paper describes the epidemiology, clinical signs, prevention, and treatment of the fish diseases attributed to this pathogen, which are similar despite the different geographic labels. In addition, the basic biology of $F$. psychrophilum and the techniques required for successful bacterial culture, isolation, and identification are discussed.

\section{EPIDEMIOLOGY}

Davis [3] first named an infection due to Flavobacterium psychrophilum as peduncle disease. According to Wood [4], a similar infection was called low temperature disease in 1949 because of its propensity to occur at cooler water temperatures. F. psychrophilum infections have also been labeled as fin rot disease [5], saddleback disease [6], fry mortality syndrome $[7,8]$, rainbow trout fry syndrome $[9,10]$, rainbow trout fry mortality syndrome [11], bacterial disease of cold water [12], coldwater disease [13] and bacterial coldwater disease $[14,15]$. Bacterial coldwater disease (BCWD) has become the established name in North America, where $F$. psychrophilum infections were first reported, whereas rainbow trout fry syndrome is the common disease name in Europe, where the disease etiology was not initially known $[16,17]$. BCWD will be used in the remainder of this

*Address correspondence to this author at the South Dakota Department of Game, Fish and Parks McNenny State Fish Hatchery 19619 Trout Loop Spearfish, South Dakota USA 57783; Tel: 605-642-1262;

Fax: 605-642-6921; E-mail: mike.barnes@state.sd.us paper to denote any of these infections caused by $F$. psychrophilum.

Flavobacterium psychrophilum infections are found throughout the world $[18,19]$. BCWD has been identified throughout North America [14, 20], nearly every country in Europe [8, 21-25], Australia [26], Chile [27], Peru [12], Japan [27, 28], Korea [29], and Turkey [30, 31].

Juvenile rainbow trout and coho salmon are particularly susceptible to BCWD [1, 2, 15, 32, 33]. However, F. psychrophilum infections have been reported in a wide range of both anadromous and non-anadromous salmonids of various sizes [34-42]. In addition, F. psychrophilum has either caused disease or been detected in Japanese eel Anguilla japonica [43], European eel Anguilla anguilla [44], common carp Cyrpinus carpio[44], crucian carp Carassius carassius [44], tench Tinca tinca [44], ayu Plecoglossus altivelis [27, 29], pale chub Zaco platypus [28], perch Perca fluviatilis [45], and roach Rutilis rutilis [45].

\section{PATHOGENESIS}

The biology of infection by Flavobacterium psychrophilum begins with the presence of the pathogen. F. psychrophilum is most likely in the aquatic environment and can likely survive for several months or even years in fresh water outside a fish host [46-50]. It may also be present via a fish reservoir [25], with live infected fish shedding $10 \times 10^{3}$ to $10 \mathrm{x}$ $10^{7}$ bacterial cells/fish/h into water [45]. Dead fish release even greater numbers of bacteria [51]. While there is some discrepancy over the presence of the bacteria on healthy fish skin, breaks in the tegument are the most likely invasion routes into the fish [45, 52, 53]. Madetoja et al. [45] observed that an abrasion of the skin and associated mucus greatly increased $F$. psychrophilum invasion. Likewise, Miwa and Nakayasu [53] recovered the bacteria only from damaged skin, even if inflicted injuries were only micro- 
scopic, and emphasized that skin injuries are a major portal for $F$. psychrophilum entry. The bacterium likely has an affinity for the lower jaw, fin, and caudal peduncle [54, 55]. The infectivity of $F$. psychrophilum may be influenced by the presence of other infectious or noninfectious organisms [52]. Busch et al. [56] suggested that ectoparasites may enhance the invasiness of $F$. psychrophilum. Degraded water chemistry, such as high organic loads or elevated nitrite concentrations, may also play a role $[57,58]$.

Vertical transmission from the brood female is highly probable $[59,60]$. This was not supported by Madsen and Dalsgaard [61] however, who could not recover F. psychrophilum within the egg and questioned the Taylor [60] methodology. Madsen and Dalsgaard [61] believe F. psychrophilum to be intimately connected with the egg membrane, but not within the egg itself. Numerous researchers have noted $F$. psychrophilum on the exterior of the egg, in milt, and in ovarian fluid [36, 59-65]. Ekman et al. [10] mimicked vertical transmission by injecting $F$. psychrophilum into adult rainbow trout. Kumagai [66] recovered F. psychrophilum cells within salmonid eggs by experimentally immersing them in a $F$. psychrophilum suspension prior to water-hardening. Resistance to vertically-transmitted $F$. psychrophilum may also be influenced by the maternal transfer of contaminants such as PCBs [67].

Upon entry into the fish, F. psychrophilum secretes psychrophilic protease [68-70]. Nematollahi et al. [58] noted a negative relationship between temperature and bacterial attachment. The bacteria create tubular boreholes to obtain $\mathrm{Ca}$ for further protease activation [55, 70]. After entering the dermis, F. psychrophilum spreads through collagenous connective tissue, for which it has a high affinity, and further expands into the musculature $[53,71]$. Open ulcers are created, with subsequent lesions on the internal organs $[53,71]$.

Flavobacterium psychrophilum strongly suppresses the nonspecific humoral defense mechanisms of the infected fish [72]. Lammens et al. [73] observed that in the presence of phagocytes bacterial numbers decreased, but this decrease was not due to phagocytic action. Viable bacteria have been noted inside spleen phagocytes [52,74], which may protect them against humoral defense mechanisms such as complement and lysozyme activity [52]. Wiklund and Dalsgaard [75] observed that high complement activity in rainbow trout sera did not reduce the number of $F$. psychrophilum cells. Because of reduced reactive oxygen species, spleen macrophages might provide a safe location for $F$. psychrophilum to minimize exposure to the immune system of the infected fish [76]. LaFrentz et al. [77, 78] noted that both non-specific immune actions and a specific antibody are needed to induce an effective immune response against $F$. psychrophilum.

F. psychrophilum has at least three main serotypes [18, $24,43]$. There are also a number of distinct genetic lineages, with the number appearing to increase with the refinement of molecular DNA techniques [19, 20, 40, 79] with considerable genetic variation and variation in virulence among strains [19, 25, 45, 80, 81]. Strain virulence may also be fish species specific [42]. Based on RAPD (Random Amplification of Polymorphic DNA) results, Chakroun et al. [83] suggested that North America was the source of F. psychrophilum in Asia, and a separate strain from Europe was trans- ferred to Australia and then back to Europe. However, using nucleotide polymorphisms from $F$. psychrophilum worldwide, Nicolas et al. [19] found no evidence that North America was the original source of $F$. psychrophilum and that there was a wide diversity of strains in Europe, particularly in wild, non-salmonids. Nicolas et al. [19] suggested that human activities likely facilitated the spread of the main two F. psychrophilum clonal complexes.

\section{CLINICAL SIGNS AND DIAGNOSIS}

The erosion of tissue, particularly involving the caudal peduncle or caudal fin, is a classic characteristic of BCWD [3, 6]. Martínez et al. [55] noted that one of the first signs of an infection is the development of whitish material along a fin margin, followed by progressive necrosis. However, even if the fin erosion or characteristic peduncle necrosis is not evident, other clinical signs of BCWD are numerous. Signs such as lower jaw skin ulcerations, pale or necrotic gills, epidermal hyperplasia, increased mucus production, increased pigmentation (particularly posteriorly, resulting in "black tail"), ascites, lethargy, scleritis, blindness, anemia, enlarged speen, intestinal inflammation, exophthalmia, pale liver and kidney, nervous disorders, spinal abnormalities, hemorrhagic and protruding anus, and spiral swimming behavior have also been reported [7,12, 14, 22, 34, 54, 84-94]. Larger fish may be more likely to exhibit necrotic lesions associated with classic BCWD [17, 95], where as histological indications are similar among all external manifestations of F. psychrophilum infection [17]. Nuerological symptoms, including spiral swimming, or deformities such as spinal compressions may be present long after an infection $[1,85$, 93].

Histologically, necrosis of most of the internal organs has been observed [7, 17, 46, 63, 87, 96, 97]. F. psychrophilum is strongly associated with phagocytes in the kidney and spleen $[74,97,98]$. The spleen is particularly affected, with hemosiderosis [87], hemorrhages [17], necrosis [17, 74, 97], and the presence of numerous bacteria $[17,74,97,99] . F$. psychrophilum has also been observed in retina and choroid gland of the eye [71].

Reported mortality from BCWD has varied. The highest reported mortality rate has been $90 \%$ in rainbow trout [25]. Mortality rates of $85 \%$ in steelhead (anadromous rainbow trout) have been reported by Brown et al. [59] with up to $70 \%$ mortality in rainbow trout from Western Europe by Santos et al. [22], Lorenzen et al. [7] and Bruno [87], and in Turkey by Kum et al. [31]. In contrast, Jensen et al. [100] reported an average of $34 \%$ rainbow trout mortality from BCWD in Denmark, Bruno [87] estimated mortalities between 10 and $30 \%$ in the UK, and Gultepe and Tanrikul [30] reported 20\% mortality in Turkey. Wood [4] and Holt [14] noted mortality rates of up to $50 \%$ in coho salmon fry. Mortalities ranging from 5 to $30 \%$ are typically experienced in slightly larger coho fingerlings [4, 14, 16, 101]. Losses from BCWD in cutthroat trout Oncorhynchus clarki have been reported to range from 30 to $45 \%$ [94, 102], and Schachte [34] noted $25 \%$ mortality in lake trout Salvelinus namaycush. Post [5] indicated that mortality could be very low (1\%) and continuous, but could reach up to $75 \%$ in a severe epizootic. 
The observed differences in fish mortality rates are likely due to a number of reasons. Water temperature is one key factor [103]. Although the disease mostly occurs from 4 to $10^{\circ} \mathrm{C}[4,5]$, it is most severe at $15^{\circ} \mathrm{C}$ [1]. Wood [4] noted increasing mortality in coho salmon with increasing water temperatures from 10 to $16^{\circ} \mathrm{C}$. Slighter higher water temperatures from 16 to $21^{\circ} \mathrm{C}$ are typical in BCWD outbreaks in ayu in Japan [104].

Bacterial virulence is also extremely important in determining the severity of BCWD epizootics [103]. There are large numbers of serologically and genetically different $F$. psychrophilum strains with highly variable virulence $[19,45$, 105], perhaps due to plasmid or siderophor influences [106]. The pathogenic strains themselves are also heterogeneous [20]. Different strains have exhibited different resistance to rainbow trout macrophage activity [76]. The genetics of the fish themselves also contributes to different mortality rates. Johnson et al. [107] noted a large variability in mortality after challenging 71 full sib families with $F$. psychrophilum.

\section{BACTERIAL CULTURE AND PATHOGEN IDENTI- FICATION}

Davis [3] first observed bacterial rods from scrapings of rainbow trout Oncorhynchus mykiss caudal penduncle lesions. Borg [108], observing similar clinical symptoms in coho salmon $O$. kisutch, isolated a bacterium from lesions and the kidney. Further describing the rod-shaped bacteria as gram-negative with gliding motility, no fruiting bodies or microcysts, and an inability to grow on culture media above $25^{\circ} \mathrm{C}$, Borg [6] classified it with myxobacteria and named it Cytophaga psychrophila. Lewin [109] suggested renaming it Flexibacter aurantiacus, and this name was used approximately 20 years later by Starliper et al. [110]. Based on DNA homology, Bernardet and Grimont [111] contended that this species should be reclassified and renamed Flexibacter psychrophilus, order Cytophagales. Subsequently, it was again reclassified into the family Flavobacteriaceae and renamed Flavobacterium psychrophilum [112]. These taxonomic changes have not been without some confusion and controversy however [113-115].

Pacha [84], Holt [14], and Madetoja et al. [41] describe F. psychrophilum as a weakly refractile, slender, gramnegative, flexible rod-shaped bacterium. Gliding motility occurs $[84,111]$, but is strongly influenced by nutrient concentrations [116]. In addition, the extent of gliding motility varies considerably, with substantial variation between strains [82, 117]. Pacha describes its size as approximately $0.75 \mu \mathrm{m}$ in diameter and 1.5 to $7.5 \mu \mathrm{m}$ in length. In contrast, Bernadart and Kerouault [21] describe the bacteria range in length as 3 to $10 \mu \mathrm{m}$, and Post [5] described it having a diameter from 0.7 to $1.5 \mu \mathrm{m}$, and length from 5 to $100 \mu \mathrm{m}$. Age may affect the length of this species [118]. Optimal incubation temperature is 18 to $20^{\circ} \mathrm{C}$, with no growth occurring at temperatures of $30^{\circ} \mathrm{C}$ or greater [21, 84, 119]. F. psychrophilum is strictly aerobic and exhibits variable colony morphology $[11,84]$. On cytophaga agar, F. psychrophilum colonies appear as bright yellow colonies with thin spreading margins $[18,84]$.

Flavobacterium. psychrophilum is only weakly reactive to chemical tests [120], however it is highly proteolytic, and can hydrolyze casein, digest albumin, hydrolyze tributyrin, and peptonize litmus milk $[68,69,106,111]$. It will produce catalase $[84,101]$ and oxidase $[111,117]$. None of the $F$. psychrophilum strains evaluated thus far can hydrolyze starch or utilize carbohydrates [21, 84]. The bacterium does not produce hydrogen sulfide, reduce nitrite to nitrate, produce cytochrome oxidase, degrade chitin, decompose cellulose, or hydrolyze xanthine [84]. Pacha [84] noted that $F$. psychrophilum would grow in $0.8 \% \mathrm{NaCl}$, but growth was inhibited at concentrations of $2.0 \%$. However, Bernardet and Kerouault [21] observed no growth at $\mathrm{NaCl}$ concentrations greater than $0.5 \%$. This discrepancy could be possible explained by differences between $F$. psychrophilum strains.

Being somewhat fastidious, $F$. psychrophilum can be difficult to both culture and isolate [117, 121, 122]. Several different agars have been used to grow $F$. psychrophilum in the laboratory, such as numerous variations of cytophaga agar [8, 21, 84, 96, 123-127]. Tryptone-yeast extract and tryptone-yeast extract-salts agar have also been used [45, 121]. Antibiotic-containing media has also been used [128, 129]. Comparing several media, Cepeda et al. [119] found that tryptone-yeast extract-salts agar with added glucose was the most effective medium at $18^{\circ} \mathrm{C}$ for isolating $F$. psychrophilum from diseased fish tissues. Antaya [2] also successfully used tryptone-yeast extract-salts agar in conjunction with incubation times of $72 \mathrm{~h}$, while Álvarez and Guijarro [122] noted improved culture results with the addition of activated charcoal to several types of media.

Other methods have improved the speed, sensitivity, and precision of detecting and identifying F. psychrophilum. Lorenzen and Karas [130] used immunofluorescence to rapidly diagnose $F$. psychrophilum infections. Madetoja and Wiklund [131] considered an immunofluorescent antibody technique an improvement over traditional plate culture. ELISA (enzyme-linked immunosorbent assay) and fluorescent antibody techniques have also been used as both an identification and screening tool for F. psychrophilum [18, 132]. Álvarez et al. [133] considered ELISA to be the best diagnostic technique. An agglutination assay was used by Misaka and Suzuki [134], and Misaka et al. [135] detected and quantified viable $F$. psychrophilum using colony blotting and immunostaining.

Nakagawa and Yamasota [136] developed polymerase chain reaction (PCR) primers for $F$. psychrophilum. PCR was also used by Toyama et al. [137], Izumi and Wakabayashi [138, 139] and Bader and Schotts [140], although Toyama et al. [141] noted that the technique lacked sensitivity. Urdaci et al. [142] and Wiklund et al. [129] used PCR to detect $F$. psychrophilum in samples of infected fish tissue. Cepeda and Santos [143] described a fast and reliable PCR method specific to $F$. psychrophilum using relatively nontoxic chemicals. F. psychrophilum has been identified from formalin-fixed and wax-embedded tissue [144] using PCR. Ramsrud et al. [145] differentiated strains using a simple PCR assay. Tiirola et al. [146], Izumi et al. [147], and Soule et al. [79], used PCR-RFLP (restriction fragment length polymorphism), whereas del Cerro et al. [148] developed a multiplex PCR method combining the use of 16S rDNA with gyr $\mathrm{B}$ based primers to improve reliability and accuracy. 
Misaka and Suzuki [134] also used PCR targeting the gyrB gene in conjunction with nested PCR.

It is difficult to compare agar plate culture directly to molecular identification techniques, because the results are often strikingly different [146]. For example, F. psychrophilum was identified using PCR from trout tissues where no bacteria had been cultured using cytophaga agar [144]. Taylor and Winton [149] noted the improvement in speed, specificity, and sensitivity of nested PCR in comparison to agar plate culture. Nested PCR was also used by Baliarda et al. [120] to report viable $F$. psychrophilum cells which could not otherwise be cultured, and by Izumi et al. [150] to detect F. psychrophilum in environmental samples containing other organisms. Madetoja and Wilklund [131] suggested the use of bot nested PCR and an immunofluorescence antibody technique. More recently, Fujiwara-Nagata and Eguchi [151] described a simple and quick loop-mediated amplification assay (LAMP) method. The complete genome of F. psychrophilum has been sequenced [95].

\section{TREATMENT}

Antibiotics are the treatment method of choice during BCWD epizootics. Nifurpirinol is effective [4,5], but is not registered in the US for food fish use because it, like other nitrofurans, is carcinogenic [16]. Sulfonamides are also effective [4, 5, 152], but like nitrofurans are not registered for use on food fish in the US. Oxytetracycline has been widely used around the world for the control of BCWD [1, 5, 13, 15, $35,99]$. Amoxycillin and oxolinic acid were widely used in Europe $[99,153]$. However, antibiotic resistance to oxytetracycline (OTC), amoxycillin, and oxolinic acid developed relatively quickly $[2,32,153,154]$, leading to therapeutic treatments with florfenicol [13,30,153], which was only recently approved in the US [155].

Antibiotic resistance to F. psychrophilum is a major challenge [156]. In 1979, Wood concluded that there were no OTC-resistant strains of $F$. psychrophilum. Brunn et al. [153] reported that oxolinic acid was initially used to control BCWD in Denmark starting in 1986, but by 2000 there was $100 \%$ resistance to the antibiotic, and the use of OTC became more prevalent. From 1994 to 1998, 60 to $75 \%$ of the F. psychrophilum isolated from Danish trout farms were OTC resistant, and amoxicillin resistance was also observed [153]. Only three years later, Brunn et al. [154] reported that OTC was rarely used with BCWD in Denmark because of antibiotic resistance. Kum et al. [31] reported F. psychrophilum resistance to florfenicol. Bruun et al. [153] speculated that $F$. psychrophilum may have instrinsic resistance to potentiated sulfonamides, and Álvarez et al. [133] reported the mutation of antibiotic-resistant genes in the bacteria. The ability of $F$. psychrophilum to produce extensive antibiotic resistant biofilms likely leads to the rapid development of antibiotic resistance, as well as recurrent infections [157].

Other authors have reported BCWD therapies involving multiple chemicals or even non-antibiotics. Gultepe and Tanrikul [30] described a treatment protocol in Turkey in which a hydrogen peroxide bath was followed by feeding florfenicol-medicated diets. Post [5] described a similar treatment regime, combining an antibiotic followed by quaternary ammonium baths every three days. Shachte [35] combined a potassium permanganate treatment in conjunction with antibiotics. The purpose of the potassium permanganate immersion treatment was two-fold, reduce the $F$. psychrophilum load and expedite mortality of infected individuals, thereby eliminating them as bacterial reservoirs [45]. Potassium permanganate was also mentioned by Groff and LaPatra [1] and La Frentz and Cain [15]. In addition, they listed the use of a 10 to 30 minute, $3 \%$ salt bath as a treatment for BCWD.

Despite considerable effort, there is not yet a viable commercial vaccine for BCWD. Live attenuated strain vaccines may be possible $[158,159]$. Virulence attenuation does occur with different strains of $F$. psychrophilum [82], which allowed Álvarez et al. [158] to obtain significant disease resistance by injecting attenuated live bacteria. Kondo et al. [160] significantly improved survival following a subsequent challenge with a virulent strain by injecting formalin-killed $F$. psychrophilum into fish. Bath vaccination with heatinactivated $F$. psychrophilum worked successfully, but had to occur at least $50 \mathrm{~d}$ post-hatch [96]. Immunity has also been induced by using a non-attenuated $F$. psychrophilum bath treatment [161], and Nikoskelainen et al. [162] included $F$. psychrophilum in a polyvalent vaccine trial. Compared to using the entire $F$. psychrophilum cell, better protection was achieved by the using part of, or all, of the antigenic outer membrane [163]. Thus, the identification of specific $F$. psychrophilum antigens by Crump et al. [164] and La Frentz et al. [165, 166], may enhance vaccine development. With the successful isolation of several $F$. psychrophilum bacteriophages, phage therapy is also being investigated [105, 167]. The use of probiotic bacteria has also shown promise in vitro [168].

\section{PREVENTION}

Egg disinfection with iodophor is frequently listed as a preventive measure against BCWD $[1,15,16,35,60,94$, 99]. However, $F$. psychrophilum is very iodine tolerant, and can survive treatments of at least $100 \mathrm{mg} / \mathrm{l}$ active iodine for at least 30 minutes $[59,66]$. The relative ineffectiveness of current egg disinfection protocols against $F$. psychrophilum is evident in the spread of virulent strains around the world $[66,83]$. Cipriano [64] also noted that standard iodophor disinfection is ineffective, and experimentally showed that even triplicate iodophor treatments did not eliminate $F$. psychrophilum within the egg. Non-chemical disinfection is also possible, although Hedrick et al. [169] noted that ultraviolet doses of $42 \mathrm{mWs} / \mathrm{cm}^{2}$ do not kill $F$. psychrophilum, and that higher doses of 126 or $256 \mathrm{mWs} / \mathrm{cm}^{2}$ are required.

Avoiding or minimizing physical handling and stress is highly recommended to prevent BCWD outbreaks $[1,15$, 16]. Not only does stress and physical handling cause immunosuppression [170], physical handling also likely leads to cutaneous lesions, providing the ideal point-of-entry for the pathogen [45, 52, 53]. Ryce and Zale [94] described the typical pattern of BCWD occurrence in a Montana hatchery, and noted that outbreaks typically occurred three weeks after fish handling or moving. Reducing rearing densities is also recommended $[16,60]$.

The use of high quality diets may help prevent BCWD. Post [5] listed malnutrition as a probable primary cause underlying BCWD. A link between diet and BCWD was dem- 
onstrated by [171]. In their study, rainbow trout fed a diet with high oxidized lipid concentrations, compared to fish receiving control diets, experienced elevated mortality after a F. psychrophilum challenge.

Poor water quality was also listed one of the primary causes contributing to outbreaks of BCWD by Post [5]. Groff and LaPatra [1] and Taylor [60] both listed optimum water quality as a BCWD preventative measure. Reduced organic loads and decreased nitrite concentrations may help reduce $F$. psychrophilum infectivity $[57,58]$. Using pathogen-free water supplies, either through natural sources or via filtering, ultraviolet treatment, or ozonation, was suggested by Cipriano and Holt [16]. Elevating water temperatures, if possible, may also serve to prevent $F$. psychrophilum infections $[1,33]$.

Broodstock screening has been mentioned as a tool to prevent BCWD [1, 35]. Lindstrom et al. [132] suggested using ELISA and filtration-based fluorescent antibody tests for broodstock selection. However, Lumsden et al. [13] questioned the practicality of broodstock screening if the rearing environment is already heavily contaminated with $F$. psychrophilum.

Hadidi et al. [155] suggested genetically selecting for resistance in brood fish. Henryon et al. [172] also noted that in the absence of effective vaccines, selective breeding showed considerable promise. Resistance to BCWD in rainbow trout is moderately heritable and not adversely correlated with growth, thereby allowing for genetic improvements [173], assuming no further detrimental bacterial mutations occur.

Because dead fish are a reservoir for $F$. psychrophilum [51], removal of mortalities from rearing units is highly recommended $[13,15]$. Avoiding the introduction of wild or novel fish into existing fish stocks is another preventative measure $[1,5]$. Other preventative measures, such as maintaining infected stocks downstream in the production system, and routine equipment sanitation are also recommended.

\section{CONCLUSION AND RECOMMENDATIONS}

Despite considerable study, $F$. psychrophilum remains a serious pathogen causing substantial mortality during hatchery rearing worldwide. There are several areas for productive future research. Additional work is needed to develop rapid, accurate, and definitive diagnostic tests so that existing and novel therapies can be started as quickly as possible. While getting additional antibiotics registered for legal use would be desirable, given the financial constraints of aquaculture drug registration and the rapid development of antibiotic resistance by $F$. psychrophilum, research into the use of probiotics or immunostimulants may likely be more productive. More study of combination therapies or non-antibiotic chemical treatments would also be beneficial. Several areas of dietary research are also warranted. Nutritional improvements with enhanced dietary formulations built on established formulations may lead to changes in BCWD susceptibility. In addition, the effects of novel dietary ingredients, such as the substitution of fish meal with plant-based proteins in carnivorous fish diets, should be evaluated. Development of BCWD-resistant brood stocks should continue. Lastly, controlled research examining hatchery management techniques to reduce stress and minimize the creation of $F$. psychrophilum entrance portals, should be conducted.

\section{ACKNOWLEDGEMENTS}

We thank Rici Domenici, Jill Tycz, Sarah Zimmerman, and the anonymous peer reviewers for their assistance with this manuscript.

\section{REFERENCES}

[1] Groff JM, LaPatra SE. In: Lim CE, Webster CD. Nutrition and Fish Health New York: Haworth Press 2001; pp. 11-78.

[2] Antaya C. Current Eco-Economical Impacts of Flavobacterium psychrophilum. MMG 445 Basic Biotechnol J 2008; 4:7-12.

[3] Davis HS. Care and diseases of trout. Research Report, No. 12. United States Fish and Wildlife Service, Washington DC 1946.

[4] Wood JW. Diseases of Pacific salmon their prevention and treatment, $3^{\text {rd }}$ ed. Olympia: Washington Department of Fisheries 1979.

[5] Post GP. Textbook of fish health. New Jersey; T.F.H. Publications 1987

[6] Borg AF. Studies on myxobacteria associated with diseases in salmonid fishes. J Wildl Dis 1960; 8: 1-85.

[7] Lorenzen E, Dalsgaard I, From J, et al. Preliminary investigation of fry mortality syndrome in rainbow trout. Bull Eur Assoc Fish Pathol 1991; 11: 77-9.

[8] Toranzo AE, Barja JL. Fry mortality syndrome (FMS) in Spain. Isolation of the causative bacterium Flexibacter psychrophilis. Bull Eur Assoc Fish Pathol 1993; 13: 30-2.

[9] Rangdale RE. Rainbow trout fry syndrome. Bull Eur Assoc Fish Pat 1999; 19: 295.

[10] Ekman E, Ákerman G, Balk L, Norrgren L. Nanoinjection as a tool to mimic vertical transmission of Flavobacterium psychrophilum in rainbow trout Oncorhynchus mykiss. Dis Aquat Organ 2003; 55: 93-9

[11] Bustos PA, Calbuyahue J, Montãna J, Opazo B, Entrala P, Solervisenc R. First isolation of Flexibacter psychrophilus, as causative agent of rainbow trout fry mortality syndrome (RTFS), producing rainbow trout mortality in Chili. Bull Eur Assoc Fish Pathol 1995; 15: 162-4.

[12] León J, Ávalos R, Ponce M. Flavobacterium psychrophilum and its pathology of alevins from the El Ingenio fish farm, Huancayo. Rev Peru Biol 2009; 15: 117-24.

[13] Lumsden JS, Young K, Welsh K, MacInnes J, Russell S, Hesami S. Management approaches for coldwater disease caused by Flavobacterium psychrophilum. In Proceedings of the Canadian Freshwater Aquaculture Symposium-Aquaculture Canada 2004. St. Andrews, New Brunswick; Aquaculture Association of Canada Special Publication No. 11 2006; 111-7.

[14] Holt RA. Cytophaga psychrophila, the causative agent of bacterial cold water disease in salmonid fish. Ph.D. thesis. Oregon State University, Corvallis 1987.

[15] LaFrentz BR, Cain KD. Bacterial coldwater disease. Department of Fish and Wildlife Resources and the Aquaculture Research Institute. University of Idaho, Moscow 2004.

[16] Cipriano RC, Holt RA. Flavobacterium psychrophilum, cause of bacterial cold-water disease and rainbow trout fry syndrome. United States Department of Interior, U.S. Geological Service, National Fish Health Research Laboratory; Fish Disease Leaflet No. $86,2005$.

[17] Ekman E. Natural and experimental infections with Flavobacterium psychrophilum in salmonid fish. Ph.D. Thesis. Swedish University of Agricultural Sciences, Uppsala 2008.

[18] Toranzo AE. In: Alvarez-Pelletero P, Barja JL, Basurco B, Berthe F, Toranzo AE, ED. Report about fish bacterial diseases France: CIHEAM/FAO 2004; pp 49-89.

[19] Nicolas P, Mondot S, Achaz G, Couchenot C, Bernardet J, Duchaud E. Population structure of the fish-pathogenic bacterium Flavobacterium psychrophilum. Appl Environ Microbiol 2008; 74: 3702-9.

[20] Hesami S, Allen KJ, Metcalf D, Ostland VE, Maclnnes JI, Lumsden JS. Phenotypic and genotypic analysis of Flavobacterium psychrophilum isolates from Ontario salmonids with bacterial coldwater disease. Can J Microbiol 2008; 54: 619-29. 
[21] Bernardet J-F, Kerouault B. Phenotypic and genomic studies of "Cytophaga psychrophila" isolated from diseased rainbow trout (Oncorhynchus mykiss) in France. Appl Environ Microbiol 1989; 55: 1796-800.

[22] Santos Y, Huntly PG, Turnbull A, Hastings TS. Isolation of Cytophaga psychrophila (Flexibacter psychorphilus) in association with rainbow trout mortality in the United Kingdom. Bull Eur Assoc Fish Pathol 1992; 12: 209-10.

[23] Wiklund T, Kass K, Lönström L, Dalsgaard I. Isolation of Cytophaga psychrophila (Flexibacter psychorphilus) from wild and farmed rainbow trout (Oncorhynchus mykiss) in Finland. Bull Eur Assoc Fish Pathol Pat 1994; 14: 44-6.

[24] Lorenzen E, Olesen NJ. Characterization of isolates of Flavobacterium psychrophilum associated with coldwater disease or rainbow trout fry syndrome II: serological studies. Dis Aquat Organ 1997; 31: 209-20.

[25] Nilsen H, Olsen AB, Vaagnes $\varnothing$, et al. Systemic Flavobacterium psychrophilum infection in rainbow trout Oncorhynchus mykiss (Walbaum) farmed in fresh and brackish water in Norway. J Fish Dis $2011 ; 34: 403-8$.

[26] Schmidtke LM, Carson J. Characteristic of Flexibacter psychrophilus isolated from Atlantic salmon in Australia. Dis Aquat Organ 1995; 21: 157-61.

[27] Wakabayashi H, Toyama T, Iida T. A study on serotyping of Cytophaga psychrophila isolated from fishes in Japan. Fish Pathol 1994; 29: 101-4

[28] Iida Y, Mizokami A. Outbreaks of coldwater disease in wild ayu and pale chub. Fish Pathol 1996; 31: 157-64.

[29] Lee KB, Heo GJ. First isolation and identification of Cytophaga psychrophila from cultured ayu Korea. Fish Pathol 1998; 33: 37-8.

[30] Gultepe N, Tanrikul TT. Treatment methods of Flavobacterium psychrophilum: cause of rainbow trout fry syndrome (RFTS) and bacterial coldwater disease (BCWD) in Turkey. J Fish Int 2006; 1: 102-5.

[31] Kum C, Kirkan S, Sekkin S, Akar F, Boyacioglu M. Comparison of in vitro antimicrobial susceptibility in Flavobacterium psychrophilum isolated from rainbow trout fry. J Aquat Anim Health 2008; 20: 245-51.

[32] Dalsgaard I, Madsen L. Bacterial pathogens in rainbow trout $O n$ corhynchus mykiss (Walbaum), reared at Danish freshwater farms. J Fish Dis 2000; 23: 199-209.

[33] Chen YC, Davis MA, LaPatra SE, Cain KD, Snekvik KR, Call DR. Genetic diversity of Flavobacterium psychrophilum recovered from commercially raised rainbow trout, Oncorhynchus mykiss (Walbaum), and spawning coho salmon, O. kisutch (Walbaum). J Fish Dis 2008; 31: 765-73.

[34] Rucker RR, Earp BJ, Ordahl EJ. Infectious diseases of Pacific salmon. Trans Am Fish Soc 1953; 83: 297-312.

[35] Schachte JH. In: Meyer FP, Warren JW, Carey TG, Ed. A guide to integrated fish health management in the great lakes basin Michigan 1983; pp 193-197.

[36] Wakabayashi H, Horiuchi M, Bunya T, Hoshiai G. Outbreaks of cold-water disease in coho salmon in Japan. Fish Pathol 1991; 26: 211-2.

[37] Ekman E, Börjeson H, Johansson N. Flavobacterium psychrophilum in Baltic salmon Salmo salar brood fish and their offspring. Dis Aquat Organ 1999; 37: 159-63.

[38] Ostland VE, Byrne PJ, Lumsden JS, et al. Atypical bacterial gill disease: a new form of bacterial gill disease affecting intensively reared salmonids. J Fish Dis 1999; 22: 351-8.

[39] Amita K, HoshinoA, Honma T, Wakabayashi H. An investigation on the distribution of Flavobacterium psychrophilum in the Unikawa River. Fish Pathol 2000; 35: 193-7.

[40] Crump EM, Perry MB, Clouthier SC, Kay WW. Antigenic characterization of the fish pathogen Flavobacterium psychrophilum. Appl Environ Microbiol 2001; 67: 750-9.

[41] Madetoja J, Hänninen M-L, Hirvelä-Koski V, Dalsgaard I, Wiklund T. Phenotypic and genotypic characteristics of Flavobacterium psychrophilum from Finnish fish farms. J Fish Dis 2001; 24: 469-79.

[42] Nagai T, Nakai T. Growth of Flavobacterium psychrophilum in fish serum correlates with pathogenicity. J Fish Dis 2011; 34: 30310.

[43] Izumi S, Liu H, Aranishi F, Wakabayashi H. A novel serotype of Favobacterium psychrophilum detected using antiserum against an isolate from amago, Oncorhynchus masou rhodurus Jordan \& Gilbert, in Japan. J Fish Dis 2003 ; 26: 677-80.

[44] Lehmann J, Mock D, Stuerenberg FJ, Bernardet JF. First isolation of Cytophaga psychrophila from a systemic disease in eel and cyprinids. Dis Aquat Organ 1991; 10: 217-20.

[45] Madetoja J, Dalsgaard I, Wiklund T. Occurrence of Flavobacterium psychrophilum in fish-farming environments. Dis Aquat Organ 2002; 52: 109-18.

[46] Wood EM, Yasutake WT. Histopathology of fish, III. Peduncle (“cold-water") disease. Progressive Fish-Culturist1956; 18: 58-61.

[47] Vatsos IN, Thompson KD, Adams A. Adhesion of the fish pathogen Flavobacterium psychrophilum to unfertilized eggs of rainbow trout (Oncorhynchus mykiss) and n-hexadecane. Lett Appl Microbiol 2001; 33: 178-82.

[48] Madetoja J, Nystedt S, Wiklund T. Survival and virulence of Flavobacterium psychrophilum in water microcosms. FEMS Microbiol Ecol 2003; 43: 217-23.

[49] Michel C, Garcia C. Virulence stability in Flavobacterium psychrophilum after storage and reservation according to different procedures. Vet Res 2003; 34: 127-32.

[50] Vatsos IN, Thompson KD, Adams A. Starvation of Flavobacterium psychrophilum in broth, stream water and distilled water. Dis Aquat Organ 2003; 26: 115-26.

[51] Madetoja J, Nyman P, Wiklund T. Flavobacterium psychrophilum, invasion into and shedding by rainbow trout Oncorhynchus mykiss. Dis Aquat Organ 2000; 43: 27-38.

[52] Decostere A, Lammens M, Haesebrouck F. Difficulties in experimental infection studies with Flavobacterium psychrophilum in rainbow trout, (Oncorhynchus mykiss) using immersion, oral and anal challenges. Res Vet Sci 2000; 69:165-9.

[53] Miwa S, Nakayasu C. Pathogenesis of experimentally induced bacterial cold water disease in ayu Plecoglossus altivelis. Dis Aquat Organ 2005; 67: 93-104.

[54] Kondo M, Kawai K, Kurohara K, Oshima S. Adherence of Flavobacterium psychrophilum on the body surface of the ayu Plecoglossus altivelis. Microbes Infect 2002; 4: 279-83.

[55] Martínez JL, Casado A, Enríquez R. Experimental infection of Flavobacterium psychrophilum in fins of Atlantic salmon Salmo salar revealed by scanning electron microscopy. Dis Aquat Organ 2004; 59: 74-84.

[56] Busch S, Dalsgaard I, Buchmann K. Concomitant exposure of rainbow trout fry to Gyrodactylus derjavini and Flavobacterium psychrophilum: effects on infection and mortality of host. Vet Parasitol 2003; 117: 117-22.

[57] Garcia G, Pozet F, Michel C. Standardization of experimental infection with Flavobacterium psychrophilum, the agent of rainbow trout Oncorhynchus mykiss fry syndrome. Dis Aquat Organ 2000; 42: 191-7.

[58] Nematollahi A, Decostere A, Pasmans F, Ductaelle R, Haesebrouck F. Adhesion of high and low virulence Flavobacterium psychrophilum strains to isolated gill arches of rainbow trout Oncorhynchus mykiss. Dis Aquat Organ 2003; 55: 101-7.

[59] Brown LL, Cox WT, Levine RP. Evidence that the causal agent of bacterial cold-water disease Flavobacterium psychrophilum is transmitted within salmonid eggs. Dis Aquat Organ 1997; 29: 2138.

[60] Taylor PW. Detection of Flavobacterium psychrophilum in eggs and sexual fluids of pacific salmonids by a polymerase chain reaction assay: implications for vertical transmission of bacterial coldwater disease. J Aquat Anim Health 2004; 16: 104-8.

[61] Madsen L, Dalsgaard I. Water recirculation and good management: potential methods to avoid disease outbreaks with Flavobacterium psychrophilum. J Fish Dis 2008; 31: 799-810.

[62] Rangdale RE, Richards RE, Alderman DJ. Isolation of Cytophaga psychrophila, causal agent of rainbow trout fry syndrome (RTFS) from reproductive fluids and egg surfaces of rainbow trout (Oncorhynchus mykiss). Bull Eur Assoc Fish Pathol 1996; 16: 63-7.

[63] Ekman E, Norrgren L. Pathology and immunohistochemistry in three species of salmonids after experimental infection with Flavobacterium psychrophilum. J Fish Dis 2003; 26: 529-38.

[64] Cipriano RC. Intraovum infection caused by Flavobacterium psychrophilum among eggs from captive Atlantic salmon broodfish. J Aquat Anim Health 2005; 17: 275-283.

[65] Madsen L, Møller JD, Dalsgaard I. Flavobacterium psychrophilum in rainbow trout, Oncorhynchus mykiss (Walbaum), hatcheries: 
studies on broodstock, eggs, fry and environment. J Fish Dis 2005; 28: 39-47.

[66] Kumagai A. Bacterial coldwater disease in coho salmon. J Japan Soc Fisheries Sci 2005; 71: 645-9.

[67] Ekman E, Ákerman G, Balk L, Norrgren L. Impact of PCB on resistance to Flavobacterium psychrophilum after experimental infection of rainbow trout Oncorhynchus mykiss eggs by nanoinjection. Dis Aquat Organ 2004; 60: 31-9.

[68] Bertolini JM, Wakabayashi H, Watral VG, Whipple MJ, Rohovec JS. Electrophoretic detection of proteases from selected strains of Flexibacter psychrophilus and assessment of their variability. J Aquat Anim Health 1994; 6: 224-33.

[69] Ostland VE, Byrne PJ, Hoover G, Ferguson HW. Necrotic myositis of rainbow trout, Oncorhynchus mykiss (Walbaum): proteolytic characteristics of a crude extracellular preparation from Flavobacterium psychrophilum. J Fish Dis 2000; 23: 329-36.

[70] Secades P, Alvarez B, Guijarro JA. Purification and characterization of a psychrophilic, calcium-induced, growth-phase-dependent metalloprotease from the fish pathogen Flavobacterium psychrophilum. Appl Environ Microbiol 2001; 67: 2436-44.

[71] Evensen $\varnothing$, Lorenzen E. An immunohistochemical study of Flexibacter psychrophilus infection in experimentally and naturally infected rainbow trout (Oncorhynchus mykiss) fry. Dis Aquat Organ 1996; 25: 53-61.

[72] Siwicki AK, Pozet F, Morand M, Kazuń K, Głqbski E, Trapkowska S. Atypical bacterial gill disease in rainbow trout (Oncorhynchus mykiss): influence on non specific humoral defence mechanisms. Archiv Polish Fish 2004; 12: 5-12.

[73] Lammens M, Decostere A, Haesebrouck F. Effect of Flavobacterium psychrophilum strains and their metabolites on the oxidative activity of rainbow trout Oncorhynchus mykiss phagocytes. Dis Aquat Organ 2000; 41: 173-9.

[74] Rangdale RE, Richards RH, Alderman DJ. Histopathological and electron microscopical observations on rainbow trout fry syndrome. Vet Rec 1999; 144: 251-4.

[75] Wiklund T, Dalsgaard I. Survival of Flavobacterium in rainbow trout (Oncorhynchus mykiss) serum in vitro. Fish Shellfish Immunol 2002; 12: 141-53.

[76] Nematollahi A, Pasmans F, Haesebrouck F, Decostere A. Early interactions of Flavobacterium psychrophilum with macrophages of rainbow trout Oncorhynchus mykiss. Dis Aquat Org 2005; 64: 23-8.

[77] LaFrentz BR, LaPatra SE, Jones GR, Congleton JL, Sun B, Cain KD. Characterization of serum and mucosal antibody responses and relative per cent survival in rainbow trout, Oncorhynchus mykiss (Walbaum), following immunization and challenge with Flavobacterium psychrophilum. J Fish Dis 2002; 25: 703-13.

[78] LaFrentz BR, LaPatra SE, Jones GR, Cain KD. Passive immunization of rainbow trout, Oncorhynchus mykiss (Walbaum), against Flavobacterium psychrophilum the causative agent of bacterial coldwater disease and rainbow trout fry syndrome. J Fish Dis 2003; 26: 377-84.

[79] Soule M, LaFrentz S, Cain K, LaPatra S, Call DR. Polymorphisms in 16S rRNA genes of Flavobacterium psychrophilum correlate with elastin hydrolysis and tetracycline resistance. Dis Aquat Organ 2005; 65: 209-16.

[80] Izumi S, Aranishi F. Plasmid profiling of Japanese Flavobacterium psychrophilum isolates. J Aquat Anim Health 2004; 16: 99-103.

[81] Soule M, Cain K, LaFrentz S, Call DR. Combining suppression subtractive hybridization and microarrays to map the intraspecies phylogeny of Flavobacterium psychrophilum. Infect Immun 2005; 73: 3799-802.

[82] Álvarez B, Secades P, Prieto M, McBride MJ, Guijarro JA. A mutation in Flavobacterium psychrophilum tlpB inhibits gliding motility and induces biofilm formation. J Appl Microbiol 2006; 72: 4044-53.

[83] Chakroun C, Grimont F, Urdaci MC, Bernardet J. Fingerprinting of Flavobacterium psychrophilum isolates by ribotyping and plasmid profiling. Dis Aquat Organ 1998; 33: 167-77.

[84] Pacha RE. Characteristics of Cytophaga psychrophila (Borg) isolated during outbreaks of bacterial cold-water disease. Appl Microbiol 1968; 16: 97-101.

[85] Kent ML, Groff JM, Morrison JK, Yasutake WT, Holt RH. Spiral swimming behavior due to cranial and vertebral lesions associated with Cytophaga psychrophila infections in salmonid fishes. Dis Aquat Organ 1989; 6: 11-6.
[86] Meyers TR. Apparent chronic bacterial myeloencephalitis in hatchery-reared juvenile coho salmon Oncorhynchus kisutch in Alaska. Dis Aquat Organ 1989; 6: 217-9.

[87] Bruno DW. Cytophaga psychrophila (Flexibacter psycrophilus) (borg), histopathology associated with mortalities among farmed rainbow trout, Oncorhynchus mykiss (Walbaum), in the UK. B Eur Assoc Fish Pat 1992; 12: 215-6.

[88] Dalsgaard I. Virulence mechanism in Cytophaga psychrophila and other Cytophaga-like bacteria pathogenic for fish. Annu Rev Fish Dis 1993; 3: 127-44.

[89] Bruno DW, Ellis AE. Salmonid disease management In: Pennell W Ed. Principles of Salmonid Culture Missouri: Elsevier 1996; 29: 729-824.

[90] Lumsden JS, Ostland VE, Ferguson HW. Necrotic myositis in cage cultured rainbow trout, Oncorhynchus mykiss (Walbaum) by Flexibacter psychrophilus. J Fish Dis 1996; 19: 113-9.

[91] Ostland VE, McGrogan DG, Ferguson HW. Cephalic steochondritis and necrotic schleritis in intensively reared salmonids associated with Flexibacter psychrophilus. J Fish Dis 1997; 20: 443-51.

[92] Madsen L, Dalsgaard I. Vertebral column deformities in farmed rainbow trout (Oncorhynchus mykiss). Aquaculture 1999; 171: 418 .

[93] Madsen L, Arnbjerg J, Dalsgaard I. Radiological examination of the spinal column in farmed rainbow trout Oncorhynchus mykiss (Walbaum): Experiments with Flavobacterium psychrophilum and oxytetracycline. Aquac Res 2001; 32: 235-41.

[94] Ryce EKN, Zale AV. Bacterial coldwater disease in westslope cutthroat trout: hatchery epidemiology and control. Final Report to the Wild Fish Habitat Initiative. Montana Water Center, Montana State University, Bozeman 2004.

[95] Duchaud E, Boussaha M, Loux V, et al. Complete genome sequence of the fish pathogen Flavobacterium psychrophilum. Nat Biotechnol 2007; 25: 763-9.

[96] Obach A, Baudin-Laurencin A. Vaccination of rainbow trout $O n$ corhynchus mykiss against the visceral form of coldwater disease. Dis Aquat Organ 1991; 12: 13-5.

[97] Decostere A, D’Haese E, Lammens M, Nells H, Haesebrouck F. In vivo study of phagocytosis, intracellular survival and multiplication of Flavobacterium psychrophilum in rainbow trout, Oncorhynchus mykiss (Walbaum), spleen phagocytes. J Fish Dis 2001; 24: 481-7.

[98] Wiklund T, Dalsgaard I. Association of Flavobacterium psychrophilum with rainbow trout (Oncorhynchus mykiss) kidney phagocytes in vitro. Fish Shellfish Immunol 2003; 15: 387-95.

[99] Branson EJ. Rainbow trout fry syndrome: an update. Fish Vet J 1998; 2: 63-6.

[100] Jensen PA, Henriksen NH, Michelsen K, Madsen L, Dalsgaard I. Prevention of RTFS (rainbow trout fry syndrome) and limitation of medicine requirements in egg and fry stocks on Danish fish farms. DGU-Rapport No. 124-03; Charlottenlund: Danish Institute for Fisheries Research 2003.

[101] Pacha RE, Porter S. Characteristics of myxobacteria isolated from the surface of freshwater fish. Appl Microbiol 1968; 16: 1901-6.

[102] Pravacek J, Barnes ME. Lack of effect of iodophor on survival of westslope cutthroat trout eggs during water hardening. North Am Aquaculture 2003; 65: 266-8.

[103] Noga EJ. Fish disease diagnosis and treatment Iowa: Blackwell Professional Publishing 2000.

[104] Asakawa M, Kiyota S, Matsuo R, Nambu T. Outbreaks of bacterial coldwater disease in ayu in Kumamoto Prefecture. Memoirs of the Faculty of Education, Kumamoto University, Natural Science 2000; 49: 47-55.

[105] Stenholm AR, Dalsgaard I, Middelboe M. Isolation and characterization of bacteriophages infecting the fish pathogen Flavobacterium psychrophilum. J Appl Microbiol 2008; 74: 4070-8.

[106] Møller JD, Ellis AE, Barnes AC, Dalsgaard I. Iron acquisition mechanisms of Flavobacterium psychrophilum. J Gen Microbiol 2005; 28: 391-8.

[107] Johnson NA, Vallejo RL, Silverstein JT, et al. Suggestive association of major histocompatibility IB genetic markers with resistance to bacterial cold water disease in rainbow trout (Oncorhynchus mykiss). Mar Biotechnol 2008; 10: 429-37.

[108] Borg AF. Studies on myxobacteria associated with diseases in salmonid fishes. Ph.D. dissertation. Seattle: University of Washington, 1948.

[109] Lewin RA. A classification of flexibacteria. J Gen Microbiol 1969; 58: 189-206. 
[110] Starliper CE, Shotts Jr EB , Hsu T, Schill WB. Genetic relatedness of some gram-negative yellow pigmented bacteria from fishes and aquatic environments. Microbiology 1998; 56: 181-98.

[111] Bernardet J-F, Grimont P. Deoxyribonucleic acid relatedness and phenotypic characterization of Flexibacter columnaris sp. nov., nom. rev., Flexibacter psychrophilus sp. nov., nom. rev., Flexibacter maritimus Wakabayashi, Hikida, and Masumura 1986. Int J Syst Bacteriol 1989; 39: 346-54.

[112] Bernardet J-F, Segers P, Vancanneyt M, Berthe F, Kerstes K, Vandamme P. Cutting a Gordian knot: emended classification and description of the genus Flavobacterium, emended description of the family Flavobacteriaceae, and proposal of Flavobacterium hydatis nom. No. (basonym, Cytophaga aquatilis Strohl and Tait 1978). Int J Syst Bacteriol 1996; 46: 128-48.

[113] Bader JA, Shotts, Jr E. Determination of phylogenetic relationships of Flavobacterium psychrophilum (Flexibacter psychrophilus), Flavobacterium columnare (Flexibacter columnaris), and Flexibacter maritimus by sequence analysis of $16 \mathrm{~S}$ ribosomal RNA genes amplified by polymerase chain reaction. J Aquat Anim Health 1998; 10: 320-7.

[114] Bernardet J-F. Comment: Phylogeny of Flavobacterium and Flexibacter. J Aquat Anim Health 2001; 13: 69-71.

[115] Bader JA, Shotts, Jr EB. Phylogeny of Flavobacterium and Flexibacter: Response to comment. J Aquat Anim Health 2001; 13: 712.

[116] Pérez-Pascual D, Menéndez A, Fernández L, Mendéz J, Reimundo P, Navais R, Guijarro J. Spreading versus biomass production by colonies of the fish pathogen Flavobacterium psychrophilum: role of nutrient concentration. Int Microbiol 2009; 12: 207-14.

[117] Nematollahi A, Decostere A, Pasmans F, Haesebrouck F. Flavobacterium psychrophilum infections in salmonid fish. J Fish Dis 2003; 26: 563-74.

[118] Austin B, Austin DA. Bacterial fish pathogens: disease in farmed and wild fish New York: John Wiley and Sons 1987.

[119] Cepeda C, García-Márquez S, Santos Y. Improved growth of Flavobacterium psychrophilum using a new culture medium. Aquaculture 2004; 238: 75-82.

[120] Baliarda A, Faure D, Urdaci MC. Development and application of a nested PCR to monitor brood stock salmonid ovarian fluid and spleen for detection of the fish pathogen Flavobacterium psychrophilum. J Appl Microbiol 2002; 92: 510-6.

[121] Michel C, Antonio D, Hendrick RP. Production of viable cultures of Flavobacterium psychrophilum approach and control. Res Microbiol 1999; 150: 351-8.

[122] Álvarez B, Guijarro JA. Recovery of Flavobacterium psychrophilum viable cells using a charcoal-based medium. Lett Appl Microbiol 2007; 44: 569-72.

[123] Anacker RL, Ordahl EJ. Studies on the myxobacterium Chondrococcus Columnaris: I. Serological typing. J Bacteriol 1959; 78: 2532.

[124] Wakabayashi H, Egusa S. Characteristics of myxobacteria associated with some freshwater diseases in Japan. Bull Jap Soc Sci Fish 1974; 40: 751-7.

[125] Lorenzen E. The importance of the beef extract in relation to the growth of lexibacter psychrophilus in Anacker and Ordal's medium. Bull Eur Assoc Fish Path 1993; 13: 64-5.

[126] Lorenzen E, Dalsgaard I, Bernardet J-F. Characterization of isolates of Flavobacterium psychrophilum associated with coldwater disease or rainbow trout fry syndrome I: phenotypic and genomic studies. Dis Aquat Organ 1997; 31: 197-208.

[127] Daskalov H, Austin DA, Austin B. An improved growth medium for Flavobacterium psychrophilum. Lett Appl Microbiol 1999, 28: 279-99.

[128] Schmidt AS, Bruun MS, Daalsgard I, Pedersen K, Larsen JL. Occurrence of antimicrobial resistance in fish-pathogenic and environmental bacteria associated with four Danish rainbow trout farms. Appl Environ Microbiol 2000; 66: 4908-15.

[129] Wiklund T, Madsen L, Bruun MS, Dalsgaard I. Detection of Flavobacterium psychrophilum from fish tissue and water samples by PCR amplification. J Appl Microbiol 2000; 88: 299-307.

[130] Lorenzen E, Karas N. Detection of Flexibacter psychrophilus by immunofluorescence in fish suffering from fry mortality syndrome: a rapid diagnostic method. Dis Aquat Organ1992; 13: 3231-4.

[131] Madetoja J, Wiklund T. Detection of the fish pathogen Flavobacterium psychrophilum in water from fish farms. Syst Appl Microbiol 2002; 25: 259-66.
[132] Lindstrom NM, Call DR, House ML, Moffitt CM, Cain KD. A quantitative enzyme-linked immunosorbent assay and filtrationbased fluorescent antibody test as potential tools to screen broodstock for infection with Flavobacterium psychrophilum. J Aquat Anim Health 2009; 21: 43-56.

[133] Álvarez B, Secades P, McBride MJ, Guijarro JA. Development of genetic techniques for the psychrotrophic fish pathogen Flavobacterium psychrophilum. J Appl Microbiol 2004; 70: 581-7.

[134] Misaka N, Suzuki K. Detection of Flavobacterium psychrophilum in chum salmon Oncorhynchus keta and virulence of isolated strains to salmonid fishes. Fish Pathol 2007; 42: 201-9.

[135] Misaka N, Nishizawa T, Yoshimizu M. Quantitative detection of viable Flavobacterium psychrophilum in chum salmon Oncorhynchus keta by colony blotting and immunostaining. Fish Pathol 2008; 43: 117-23.

[136] Nakagawa Y, Yamasoto K. Phylogenetic diversity of the genus Cytophaga revealed by 16S rRNA sequencing and menaquinone analysis. J Gen Microbiol 1993; 139: 1155-61.

[137] Toyama T, Kita-Tsukamoto K, Wakabayshi H. Identification of Cytophaga psychrophila by PCR targeted 16S ribosomal RNA. Fish Pathol 1994; 29: 271-5.

[138] Izumi S, Wakabayashi H. Use of PCR to detect Cytophaga psychrophila from apparently healthy juvenile ayu and coho salmon eggs. Fish Pathol 1997; 32: 169-73.

[139] Izumi S, Wakabayashi H. Sequencing of gyrB and their application in the identification of Flavobacterium psychrophilum by PCR. Fish Pathol 2000; 35: 93-4.

[140] Bader JA, Shotts Jr E. Identification of Flavobacterium and Flexibacter species by species-specific polymerase chain reaction primers to the 16S ribosomal RNA gene. J Aquat Anim Health 1998; 10: 311-9.

[141] Toyama T, Kita-Tsukamoto K, Wakabayashi H. Identification of Cytophaga psychrophila by PCR target 16 S ribosomal DNA. Fish Pathol 1996; 29: 271-5.

[142] Urdaci MC, Chakroun C, Faure D, Bernardet JF. Development of polymerase chain reaction assay for identification and detection of the fish pathogen Flavobacterium psychrophilum. Res Microbiol 1998; 149: 519-30.

[143] Cepeda C, Santos Y. Rapid and low-level toxic PCR-based method for routine identification of Flavobacterium psychrophilum. Int Microbiol 2000; 3: 235-8.

[144] Crumlish M, Diab AM, Ferguson HW. Detection of the bacterium Flavobacterium psychrophilum from a natural infection in rainbow trout, Oncorhynchus mykiss (Walbaum), using formalin-fized, waxembedded fish tissues. J Fish Dis 2007; 30: 37-41.

[145] Ramsrud AL, LaFrentz SA, LaFrentz BR, Cain KD, Call DR. Differentiating 16S rRNA alleles of Flavobacterium psychrophilum using simple PCR assay. J Fish Dis 2007; 30: 175-80.

[146] Tiirola M, Valtonen ET, Rintamäki-Kinnunen P. Diagnosis of flavobacteriosis by direct amplification of rRNA genes. Dis Aquat Organ 2002; 51: 93-100.

[147] Izumi S, Aranishi F, Wakabayashi H. Genotyping of Flavobacterium psychrophilum using PCR-RFLP analysis. Dis Aquat Organ 2003; 56: 207-14.

[148] del Cerro A, Marquez I, Guijarro JA. Simultaneous detection of Aeromonas salmonicida, Flavobacterium psychrophilum, and Yersinia ruckeri, three major fish pathogens, by multiplex PCR. Environ Microbiol 2002; 68: 5177-80.

[149] Taylor PW, Winton JR. Optimization of nested polymerase chain reaction assays for identification of Aeromonas salmonicida, Yersinia ruckeri, and Flavobacterium psychrophilum. J Aquat Anim Health 2002; 14: 216-24.

[150] Izumi S, Fujii H, Aranishi F. Detection and identification of Flavobacterium psychrophilum from gill washings and benthic diatoms by PCR-based sequencing analysis. J Fish Dis 2005; 28: 55964.

[151] Fujiwara-Nagata E, Eguchi M. Development and evaluation of a loop-mediated isothermal amplification assay for rapid and simple detection of Flavobacterium psychrophilum. J Fish Dis 2009; 32: 873-81.

[152] Amend DF. In: Snieszko SF Ed. A Symposium on Diseases of Fishes and Shellfishes Maryland: Am Fish Soc 1970; 5: 258-65.

[153] Bruun MS, Schmidt AS, Madsen I, Dalsgaard I. Antimicrobial resistance patterns in Danish isolates of Flavobacterium psychrophilum. Aquaculture 2000; 187: 201-12. 
[154] Brunn MS, Madsen L, Dalsgaard I. Efficiency of oxytetracycline treatment in rainbow trout experimentally infected with Flavobacterium psychrophilum strains having different in vitro antibiotic susceptibilities. Aquaculture 2003; 215: 11-20.

[155] Hadidi S, Glenney GW, Welch TJ, Silverstein JT, Wiens GD. Spleen size predicts resistance of rainbow trout to Flavobacterium psychrophilum challenge. J Immunol2008; 180: 4156-65.

[156] Fryer JL, Bartholomew JL. Established and emerging infectious diseases of fish. In: Emerging and Reemerging Infectious Diseases of Plants and Animals. American Society for Microbiology, Washington, DC. 1996; pp 14-16.

[157] Sundell, K., and T. Wiklund. Effect of biofilm formation on antimicrobial tolerance of Flavobacterium psychrophilum. J Fish Dis 2011: 34: 373-83.

[158] Álvarez B, Álvarez J, Menéndez A, Guijarro JA. A mutant in one of two exbD loci of a TonB system in Flavobacterium psychrophilum shows attenuated virulence and confers protection against cold water disease. Microbiology 2008; 154: 1144-51.

[159] LaFrentz BR, Lapatra SE, Call DR, Cain KD. Isolation of rifampicin resistant Flavobacterium psychrophilum strains and their potential as live attenuated vaccine candidates.Vaccine 2008; 26: 5582-9.

[160] Kondo M, Kawai K, Okabe M, Nakano N, Oshima S. Efficacy of oral vaccine against bacterial coldwater disease in ayu Plecoglossus altivelis. Dis Aquat Organ 2003; 55: 261-4.

[161] Lorenzen E, Brudeseth BE, Wiklund T, Lorenzen N. Immersion exposure of rainbow trout (Oncorhynchus mykiss) fry to wildtype Flavobacterium psychrophilum induces no mortality, but protects against later intraperitoneal challenge. Fish Shellfish Immunol 2010; 28: 440-4.

[162] Nikoskelainen S, Verho S, Järvinen S, Madetoja J, Wiklund T, Lilius E. Multiple whole bacterial antigens in polyvalent vaccine may result in inhibition of specific responses in rainbow trout $(\mathrm{On}$ corhynchus mykiss). Fish Shellfish Immunol 2007; 22: 206-17.

[163] Rahman MH, Kuroda A, Dijkstra JM, Kiryu I, Nakanishi T, Ototake M. The outer membrane fraction of Flavobacterium psychrophilum induces protective immunity in rainbow trout and ayu. Fish Shellfish Immunol 2002; 12: 169-79.
[164] Crump EM, Burian J, Allen PD, Kay WW. Identification and expression of a host-recognized antigen, FspA, from Flavobacterium psychrophilum. Microbiology 2005; 151: 3127-35.

[165] LaFrentz BR, LaPatra SE, Jones GR, Cain KD. Protective immunity in rainbow trout Oncorhynchus mykiss following immunization with distinct molecular mass fractions isolated from Flavobacterium psychrophilum. Dis Aquat Organ 2004; 59: 17-26.

[166] LaFrentz BR, Lindstrom NM, LaPatra SE, Call DR, Cain KD. Electrophoretic and western blot analyses of the lipopolysaccharide and glycocalyx of Flavobacterium psychrophilum. Fish Shellfish Immunol 2007; 23: 770-80.

[167] Kim JH, Gomez DK, Nakai T, Park SC. Isolation and identification of bacteriophages infecting ayu Plecoglossus altivelis altivelis specific Flavobacterium psychrophilum. Vet Microbiol 2010; 140 $109-15$.

[168] Ström-Bestor M, Wiklund T. Inhibitory activity of Pseudomonas sp. on Flavobacterium psychrophilum, in vitro. J Fish Dis 2011; 34: 255-64.

[169] Hedrick RP, McDowell TS, Marty GD, et al. Ultraviolet irradiation inactivates the aterborne infective stages of Myxobolus cerebralis: a treatment for hatchery water supplies. Dis Aquat Organ 2000; 42 : 53-9.

[170] Barton BA. Stress in fishes: a diversity of responses with particular reference to changes in circulating corticosteroids. Integr Comp Biol 2002; 42: 517-25.

[171] Daskalov H, Robertson PAW, Austin B. Influence of oxidized lipids in diets on the development of rainbow trout fry syndrome. J Fish Dis 2000; 23: 7-14.

[172] Henryon M, Berg P, Olesen NJ, et al. Selective breeding provides an approach to increase resistance of rainbow trout (Oncorhynchus mykiss) to the diseases, enteric redmouth disease, rainbow trout fry syndrome, and viral haemorrhagic septicaemia. Aquaculture 2005; 250: 621-36.

[173] Silverstein JT, Vallejo RL, Palti Y, et al. Rainbow trout resistance to bacterial cold-water disease is moderately heritable and is not adversely correlated with growth. J Anim Sci 2009; 87: 860-8.

Received: May 20, 2011

Revised: June 27, 2011

Accepted: June 29, 2011

(C) Barnes and Brown et al.; Licensee Bentham Open.

This is an open access article licensed under the terms of the Creative Commons Attribution Non-Commercial License (http://creativecommons.org/licenses/ by-nc/3.0/) which permits unrestricted, non-commercial use, distribution and reproduction in any medium, provided the work is properly cited. 